Article

\title{
The Suitability of Zn-1.3\%Fe Alloy as a Biodegradable Implant Material
}

\author{
Alon Kafri ${ }^{1}$ (D), Shira Ovadia ${ }^{2}$, Jeremy Goldman ${ }^{3, *}$, Jaroslaw Drelich ${ }^{4}$ and Eli Aghion ${ }^{1}$ \\ 1 Department of Materials Engineering, Ben-Gurion University of the Negev, Beer-Sheva 8410501, Israel; \\ kafri09@gmail.com (A.K.); egyon@bgu.ac.il (E.A.) \\ 2 Faculty of Health Science, Ben-Gurion University of the Negev, P.O. Box 653, Beer-Sheva 84105, Israel; \\ shiraov@bgu.ac.il \\ 3 Department of Biomedical Engineering, Michigan Technological University, Houghton, MI 49931, USA \\ 4 Department of Materials Science and Engineering, Michigan Technological University, \\ Houghton, MI 49931, USA; jwdrelic@mtu.edu \\ * Correspondence: jgoldman@mtu.edu
}

Received: 5 February 2018; Accepted: 26 February 2018; Published: 28 February 2018

\begin{abstract}
Efforts to develop metallic zinc for biodegradable implants have significantly advanced following an earlier focus on magnesium $(\mathrm{Mg})$ and iron $(\mathrm{Fe}) . \mathrm{Mg}$ and $\mathrm{Fe}$ base alloys experience an accelerated corrosion rate and harmful corrosion products, respectively. The corrosion rate of pure $\mathrm{Zn}$, however, may need to be modified from its reported $\sim 20 \mu \mathrm{m} /$ year penetration rate, depending upon the intended application. The present study aimed at evaluating the possibility of using Fe as a relatively cathodic biocompatible alloying element in zinc that can tune the implant degradation rate via microgalvanic effects. The selected $\mathrm{Zn}-1.3 \mathrm{wt} \% \mathrm{Fe}$ alloy composition produced by gravity casting was examined in vitro and in vivo. The in vitro examination included immersion tests, potentiodynamic polarization and impedance spectroscopy, all in a simulated physiological environment (phosphate-buffered saline, PBS) at $37^{\circ} \mathrm{C}$. For the in vivo study, two cylindrical disks (seven millimeters diameter and two millimeters height) were implanted into the back midline of male Wister rats. The rats were examined post implantation in terms of weight gain and hematological characteristics, including red blood cell (RBC), hemoglobin (HGB) and white blood cell (WBC) levels. Following retrieval, specimens were examined for corrosion rate measurements and histological analysis of subcutaneous tissue in the implant vicinity. In vivo analysis demonstrated that the $\mathrm{Zn}-1.3 \% \mathrm{Fe}$ implant avoided harmful systemic effects. The in vivo and in vitro results indicate that the $\mathrm{Zn}-1.3 \% \mathrm{Fe}$ alloy corrosion rate is significantly increased compared to pure zinc. The relatively increased degradation of $\mathrm{Zn}-1.3 \% \mathrm{Fe}$ was mainly related to microgalvanic effects produced by a secondary $\mathrm{Zn}_{11}$ Fe phase.
\end{abstract}

Keywords: zinc; bioabsorbable; biodegradable; implants; encapsulation; in vivo

\section{Introduction}

The development of bioabsorbable metal implants has drawn major attention over the last two decades. Early studies mainly focused on pure $\mathrm{Fe}$ and $\mathrm{Mg}$ and their alloys. Bioabsorbable implants based on Fe exhibit good biocompatibility and excellent mechanical properties [1-5]. However, they suffer from a harmful mode of corrosion that produces a voluminous iron oxide layer [6]. The steady accumulation of the iron oxide reduces the lumen cross section, compromises the integrity of the arterial wall by repelling neighboring tissue and cells [7], and stimulates inflammation [8]. Bioabsorbable implants based on $\mathrm{Mg}$ are attractive mainly due to their excellent biocompatibility [8-20]. Unfortunately, $\mathrm{Mg}$ and its alloys exhibit an excessive corrosion rate associated 
with a potentially harmful release of hydrogen gas $[15,18]$. The challenges faced with both Fe and $\mathrm{Mg}$ systems have motivated a search for new metallic materials, among them Zn and Zn-based alloys.

Early in vivo studies with pure zinc arterial implants have reported a promising biocompatibility [21,22]. The biodegradation rate is near the projected ideal value for vascular stents, and between that of $\mathrm{Mg}$ and Fe. In addition, $\mathrm{Zn}$ has important physiological roles, exerting strong anti-atherogenic properties [23], participating in nucleic acid metabolism, signal transduction, apoptosis regulation, and gene expression [24,25]. Zinc is not toxic to the human body at the low levels expected to be released from a typical stent [26]. Our extensive preliminary observations have confirmed the lack of overt toxicity at the interface between a zinc implant and biological tissue, despite even 20 months residence time in the body [21,27-29]. However, at high levels zinc can cause toxicity, manifested in poor growth and anemia [30,31]. To avoid negative responses, the corrosion rate for zinc-based implants may need to be optimized for biodegradable application. Our previous studies demonstrated that the corrosion rate of a $\mathrm{Zn}$ implant can be reduced in the first several weeks after deployment into an arterial environment by manipulating the oxide film characteristics [32] or adding a polymeric layer [33]. In addition, earlier research carried out by the authors [27] suggested that the low degradation rate of arterial implants made from pure zinc can provoke a long-term process of inflammation and fibrous encapsulation. Encapsulation can be considered as a major factor contributing to implant failure, as it isolates the implant from the surrounding tissue and can potentially cause a discontinuation of the biodegradation process [34,35]. This was supported by Yue et al. [36] which indicated that too low degradation rate is a challenge for future application of $\mathrm{Zn}$ base alloys as adequate biodegradable implant.

The need to improve the strength of $\mathrm{Zn}$ and $\mathrm{Zn}$-based materials, manipulate their corrosion rate and improve their biocompatibility motivated the search for new Zn-based alloys [37-51]. In order to obtain a higher corrosion rate without compromising biocompatibility, the alloying element must be biocompatible and have the potential to increase the corrosion rate of the $\mathrm{Zn}$-based alloy. Since Fe is known as a biocompatible element and the intermetallic phases formed between $\mathrm{Zn}$ and Fe all have higher electrochemical potential [52,53], it was considered a suitable alloying element. The present study aimed at exploring the prospects of $\mathrm{Zn}-1.3 \mathrm{wt} \% \mathrm{Fe}$ (denoted as $\mathrm{Zn}-1.3 \% \mathrm{Fe}$ ) alloy as a biodegradable implant material in terms of in vitro and in vivo behavior.

\section{Experimental Procedure}

Ingots of pure $\mathrm{Zn}$ and $\mathrm{Zn}-1.3 \% \mathrm{Fe}$ alloy were produced by gravity casting in a rectangular steel die having the following dimensions: $6 \times 25 \times 4.5 \mathrm{~cm}$. Prior to the casting process, pure zinc bars $(99.99 \%)$ and pure iron $(99 \%)$ powder $(-325$ mesh) in the desired amount were placed in a graphite crucible and heated to $750{ }^{\circ} \mathrm{C}$ for $3 \mathrm{~h}$ in a furnace, with stirring every $30 \mathrm{~min}$. All the test samples produced from the cast ingot were machined from the central part of the ingot, producing surface roughness type N5. The chemical compositions of the obtained ingots were determined using an Inductively Coupled Plasma Optical Emission Spectrometer (ICP-SPECTRO, ARCOS FHS-12, Kelve, Germany) method, with results shown in Table 1.

Table 1. Chemical composition of pure $\mathrm{Zn}$ and $\mathrm{Zn}-1.3 \% \mathrm{Fe}$ alloy.

\begin{tabular}{cccccc}
\hline Material System & Fe (wt \%) & Pb (wt \%) & Al (wt \%) & Cu (wt \%) & Cd (wt \%) \\
\hline Pure Zn & 0.0054 & 0.0011 & 0.0026 & 0.0007 & 0.0017 \\
$\mathrm{Zn}-1.3 \% \mathrm{Fe}$ & 1.31 & 0.0010 & 0.0079 & 0.0006 & 0.0017 \\
\hline
\end{tabular}

Microstructure examination was carried out using scanning electron microscopy (SEM) with a JEOL JSM-5600 (JEOL, Tokyo, Japan) equipped with an Energy-dispersive X-ray spectroscopy (EDS) detector (Thermo Fisher Scientific, Waltham, MA, USA) for spot elemental analysis. Identification of internal phases was conducted using an X-ray diffractometer RIGAKU-2100H (RIGAKU, Tokyo, 
Japan) with $\mathrm{Cu}-\mathrm{K} \alpha$. The diffraction parameter was $40 \mathrm{kV} / 30 \mathrm{~mA}$ and the scanning rate was $2^{\circ} / \mathrm{min}$. Indication of mechanical properties was obtained by Vickers hardness measurements performed in a Zwick/Roell Indentec of Quantarad Technologies, with an applied load of $3 \mathrm{~kg}$. The tensile tests were performed at room temperature using a universal material test machine (Hounsfield H25KT, Horsham, PA, USA) at a rate of $0.5 \mathrm{~mm} / \mathrm{min}$.

The in vitro corrosion behavior was examined by an immersion test for up to 20 days, according to the ASTM G31-12a standard as well as by electrochemical characterization and stress corrosion analysis. All the in vitro corrosion tests were carried out in phosphate-buffered saline (PBS) solution at $37^{\circ} \mathrm{C}$ with $\mathrm{pH}$ levels of $\sim 7.4$. The selected corrosion medium and environmental conditions aimed at simulating the natural physiological environment [54-56]. Monitoring of $\mathrm{pH}$ levels was conducted by daily replacement of the PBS solution. The electrochemical characterization included potentiodynamic polarization analysis and impedance spectroscopy (EIS) using a Bio-Logic SP-200 potentiostat equipped with EC-Lab software V11.02. The three-electrode cell used for the electrochemical analysis included a saturated calomel reference electrode (SCE), a platinum counter electrode, and the tested sample as the working electrode, with an exposure area of $1 \mathrm{~cm}^{2}$. The scanning rate of the potentiodynamic polarization analysis was $1 \mathrm{mV} / \mathrm{s}$; the EIS measurements were carried out between $10 \mathrm{kHz}$ and $100 \mathrm{mHz}$ at $10 \mathrm{mV}$ amplitude over the open circuit potential. Prior to electrochemical testing, the samples were cleaned in an ultrasonic bath for $5 \mathrm{~min}$, washed with alcohol, and dried in hot air.

The metals used for the in vivo assessment included pure zinc as the biodegradable reference material, the $\mathrm{Zn}-1.3 \% \mathrm{Fe}$ allow, and titanium alloy $\mathrm{Ti}-6 \mathrm{Al}-4 \mathrm{~V}$ as a biostable reference material. The implant geometry of cylindrical disks of $7 \mathrm{~mm}$ diameter and $2 \mathrm{~mm}$ height was obtained by regular machining from cast $\mathrm{Zn}$ base ingots and wrought billet in the case of the titanium ally. Prior to implantation, the disks were ultrasonically cleaned in ethanol for $5 \mathrm{~min}$ and then in acetone for $3 \mathrm{~min}$ before final air drying.

All the animal experiments were approved by the Ben-Gurion University of the Negev (BGU) Committee for the Ethical Care and Use of Laboratory Animals (BGU-IACUC). The experiments were performed according to the Israel Animal Welfare law (1994) and the NRC Guide for the Care and Use of Laboratory Animals (2011). BGU's animal care and use program is approved by the Association for the Assessment and Accreditation of Laboratory Animal Care International (AAALAC). The in vivo experiments were carried out in the BGU rodent facility. Nine $250 \mathrm{~g}$ male Wistar rats (Envigo, Jerusalem, Israel) were selected for the in vivo assessment. The rats were divided into 3 groups. The first group $(n=3)$ was implanted with pure $\mathrm{Zn}$ disks, the second group $(n=3)$ with the $\mathrm{Zn}-1.3 \% \mathrm{Fe}$ alloy, and the third group $(n=3)$ with Ti-6Al-4V.

For implantation, the rats were anesthetized with an inhalation anesthesia machine using 3\% isoflurane (Terrel TM Piramal Critical Care, Inc., Bethlehem, PA, USA) in $500 \mathrm{~mL} / \mathrm{min} 100 \%$ oxygen. Two cylindrical disks were implanted aseptically subcutaneously in the midline of the back of the rats, one between scapulas and another in mid-lumbar area. Post alloy implantation, the rats were placed on a heating pad until they recovered form anesthesia and were able to ambulate. For postoperative analgesia, rats received $100 \mathrm{mg} / \mathrm{kg}$ Dipyrone (Vitamed Pharmaceutical Industries LTD, Binyamina, Israel) in the drinking water for 3 days. Rats were monitored daily for surgical wound appearance, locomotion in the cage, grooming activity and general wellbeing for the first week. This was followed by a weekly evaluation of body weight, attitude and incision appearance. Blood was collected from the retro-orbital sinus under isoflurane anesthesia as described above. Whole blood $(1 \mathrm{~mL})$ was collected in EDTA for a complete blood count for red blood cells (RBC), hemoglobin (HGB) and white blood cells (WBC). Serum $(1 \mathrm{~mL})$ was collected for determination of $\mathrm{Zn}$ levels. Blood work was analyzed on the day of implantation and at 4 and 8 weeks post-implantation. The blood biochemical parameters in terms of RBC, HGB and WBC can indicate abnormal situations, such as a significant increase in $\mathrm{Zn}$ content or infection. At 14 weeks the rats were euthanized with intraperitoneal $150 \mathrm{mg} / \mathrm{kg}$ Pentobarbital (CTS Chemical Industries Ltd., Hod Hasharon, Israel) for alloy and tissue harvest. Tissue from each alloy location was placed in $10 \%$ formaldehyde for histology. Removal 
of corrosion products to calculate the corrosion rate was preformed according to ASTM G1 using $10 \% \mathrm{NH}_{4} \mathrm{Cl}$ solution, which allowed for a calculation of the corrosion rate.

The statistical analysis was implemented using a one-way ANOVA to determine the significance of paired comparisons. A $p$ value $<0.05$ was selected for statistical difference between means.

\section{Results}

The typical microstructure of pure zinc and $\mathrm{Zn}-1.3 \%$ Fe alloy are shown in cross-sectional view (Figure 1), along with a spot chemical analysis at various points, shown in Table 2. A regular structure without any second phase is present in pure zinc. The $\mathrm{Zn}-1.3 \% \mathrm{Fe}$ alloy contained $\mathrm{Zn}$ matrix and an Fe-rich phase that was dispersed homogenously across the bulk of the alloy. The Fe content within the Fe-rich phase, as obtained by EDS analysis, was between 7 and $10 \mathrm{wt} \%$ corresponding with Fe content in the $\mathrm{Zn}$-delta phase composition [52].



Figure 1. Microstructure at cross-section of (a) Pure Zn. (b,c) Zn-1.3\%Fe alloy, macro and close-up view respectively.

Table 2. Chemical composition of $\mathrm{Zn}-1.3 \% \mathrm{Fe}$ at different points shown in Figure $1 \mathrm{~b}$.

\begin{tabular}{ccc}
\hline El Element (wt \%) Tested Area & Zn & Fe \\
\hline Point 1 & $90 \pm 1$ & $9.8 \pm 0.3$ \\
Point 2 & $100 \pm 1$ & $0.13 \pm 0.08$ \\
\hline
\end{tabular}

The X-ray diffraction analysis (Figure 2) revealed the presence of the two major phases: a pure $\mathrm{Zn}$ and Fe rich phase. Additional precipitating phases in the $\mathrm{Zn}-1.3 \% \mathrm{Fe}$ alloy appear to be Delta $\mathrm{Zn}$ (ICDD 045-1184), with a possible contribution of Zeta Zn. This result is in accordance with the EDS analysis of the Fe-rich phase. 


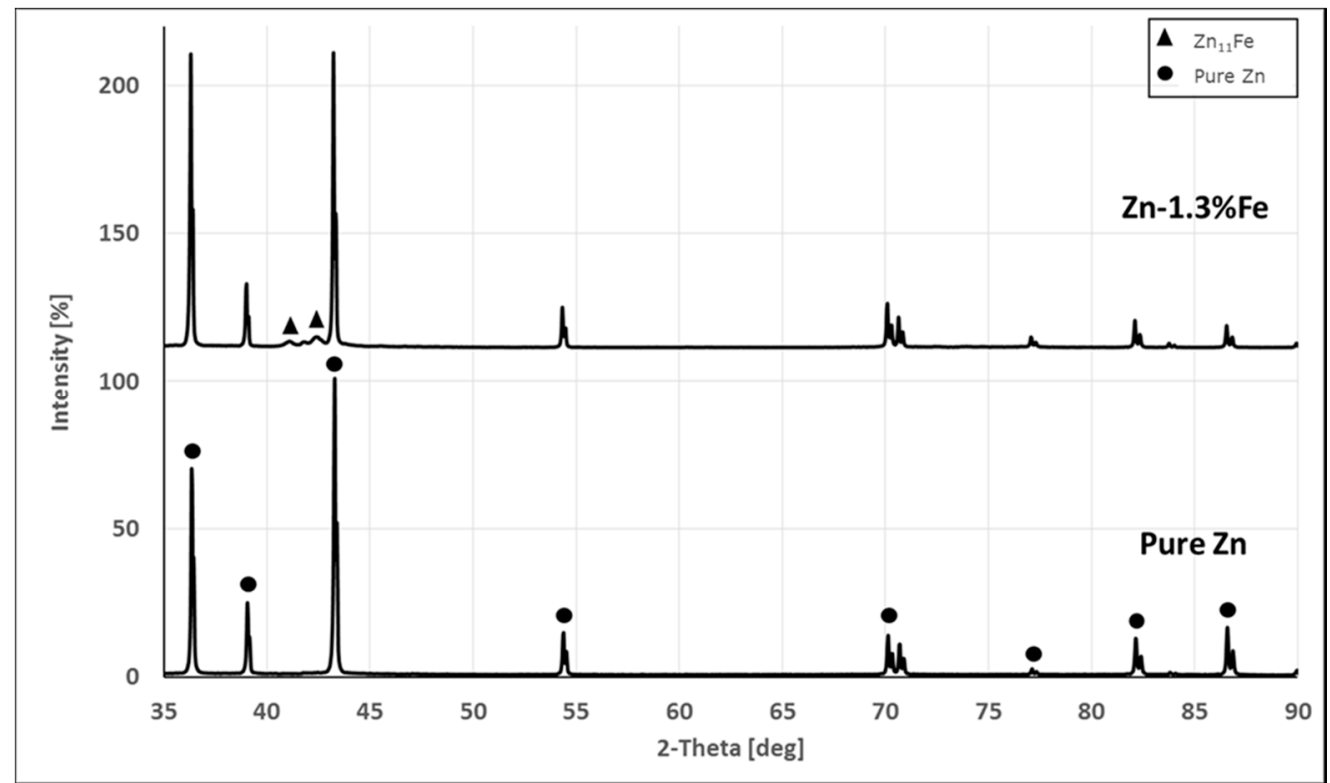

Figure 2. X-ray diffraction analysis of pure $\mathrm{Zn}$ and $\mathrm{Zn}-1.3 \%$ Fe alloy.

Hardness tests were conducted to begin evaluating the mechanical properties. The hardness of pure $\mathrm{Zn}$ and $\mathrm{Zn}-1.3 \% \mathrm{Fe}$ alloy were $40 \pm 3$ and $56 \pm 2 \mathrm{HV}$ (hardness Vickers), respectively. The increased $\mathrm{Zn}-1.3 \% \mathrm{Fe}$ alloy hardness is attributed to the additional Delta $\mathrm{Zn}$ phase.

The mechanical properties of pure $\mathrm{Zn}$ and $\mathrm{Zn}-1.3 \% \mathrm{Fe}$ alloy in as-cast conditions are shown in Figure 3. While the yield strength (YS) and ultimate tensile strength (UTS) of Zn-1.3\%Fe alloy was improved compared to pure $\mathrm{Zn}$, the ductility was relatively reduced.



Figure 3. Mechanical properties of pure $\mathrm{Zn}$ and $\mathrm{Zn}-1.3 \% \mathrm{Fe}$.

Close-up views of the external surfaces of pure $\mathrm{Zn}$ and $\mathrm{Zn}-1.3 \% \mathrm{Fe}$ alloy after immersion tests of 10 and 20 days are shown in Figure 4. While a general corrosion attack was observed in both samples, it was significantly more intense in the $\mathrm{Zn}-1.3 \% \mathrm{Fe}$ alloy for both exposure times. The corrosion attack against pure $\mathrm{Zn}$ was relatively mild and did not cover the entire sample surface, the attack against $\mathrm{Zn}-1.3 \% \mathrm{Fe}$ alloy was more severe and covered the entire sample surface. 
The calculated corrosion rates for pure $\mathrm{Zn}$ and $\mathrm{Zn}-1.3 \% \mathrm{Fe}$ alloy, as obtained by the immersion tests, are shown in Figure 5. The corrosion rate of the $\mathrm{Zn}-1.3 \% \mathrm{Fe}$ alloy was nearly twice that of pure $\mathrm{Zn}$ after 10 and 20 days of exposure.
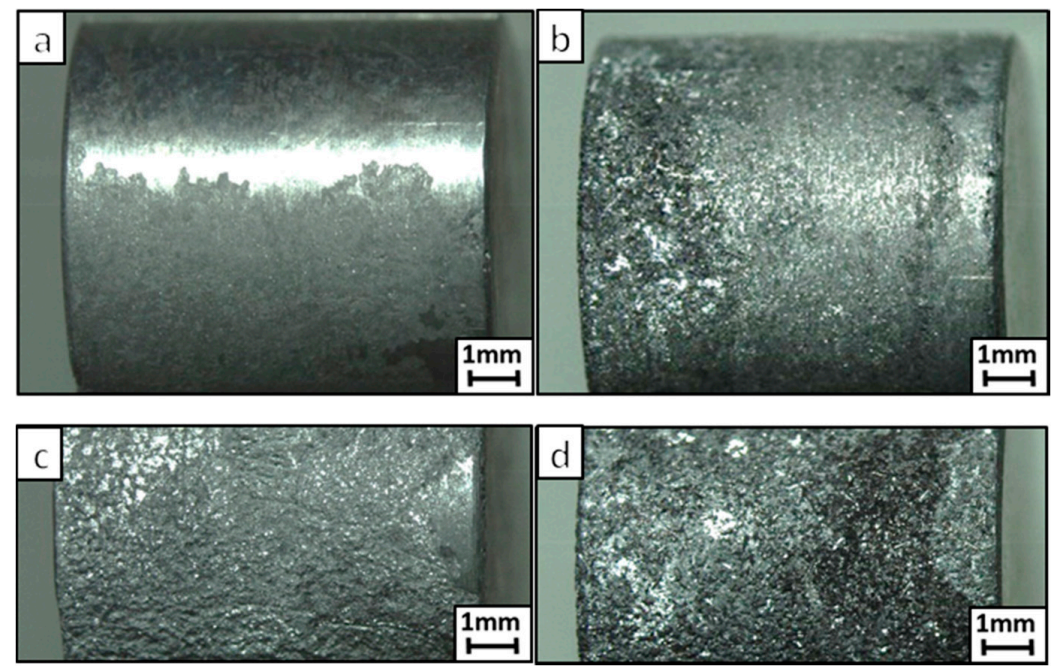

Figure 4. Optical microscopy showing corrosion attack at the surface of pure $\mathrm{Zn}$ and $\mathrm{Zn}-1.3 \% \mathrm{Fe}$ alloy after immersion tests in phosphate-buffered saline (PBS) solution at $37^{\circ} \mathrm{C}$. (a,b) pure $\mathrm{Zn}$ and $\mathrm{Zn}-1.3 \% \mathrm{Fe}$ alloy after 10 days of exposure. (c,d) pure $\mathrm{Zn}$ and $\mathrm{Zn}-1.3 \%$ Fe alloy after 20 days of exposure.

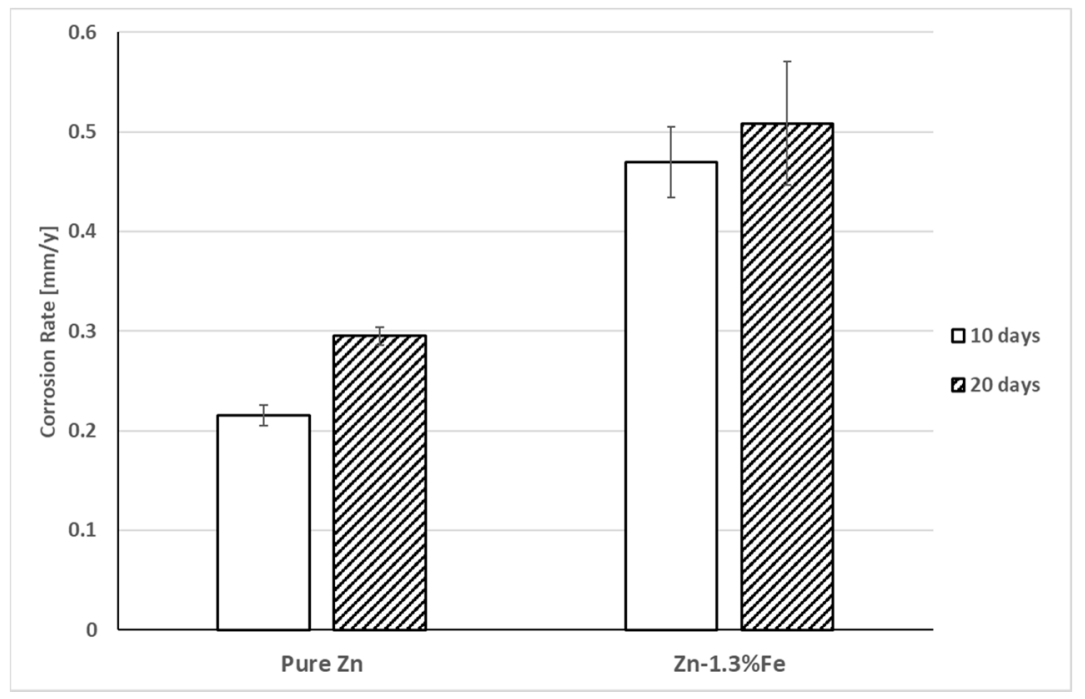

Figure 5. Corrosion rate measurements of pure $\mathrm{Zn}$ and $\mathrm{Zn}-1.3 \% \mathrm{Fe}$ alloy after immersion tests in PBS solution at $37^{\circ} \mathrm{C}$.

In order to further investigate the corrosion attack mechanism in Zn-1.3\%Fe alloy, close-up cross sectional views of the corroded area were inspected, as shown in Figure 6. The images revealed a uniform corrosion attack at the external surface (Figure 6a). This phenomenon is in line with the basic degradation requirements of biodegradable implants in terms of preserving their mechanical integrity during the critical period after implantation and undergoing degradation without risk of premature implant fracture during the mechanical scaffolding phase. At higher magnification (Figure 6b), intact $Z \mathrm{n}_{11} \mathrm{Fe}$ particles are seen in the vicinity of corroded matrix. In accordance with our hypothesis, the cathodic $\mathrm{Zn}_{11}$ Fe particles ( -0.87 Vsce vs. -1.03 Vsce for pure $\mathrm{Zn}$ [53]) acted as a cathodic phase 
to the $\mathrm{Zn}$ matrix, causing accelerated degradation by micro-galvanic effect. This mechanism can explain the higher corrosion rate of the $\mathrm{Zn}-1.3 \% \mathrm{Fe}$ alloy compared to pure $\mathrm{Zn}$ as quantified by the immersion test.
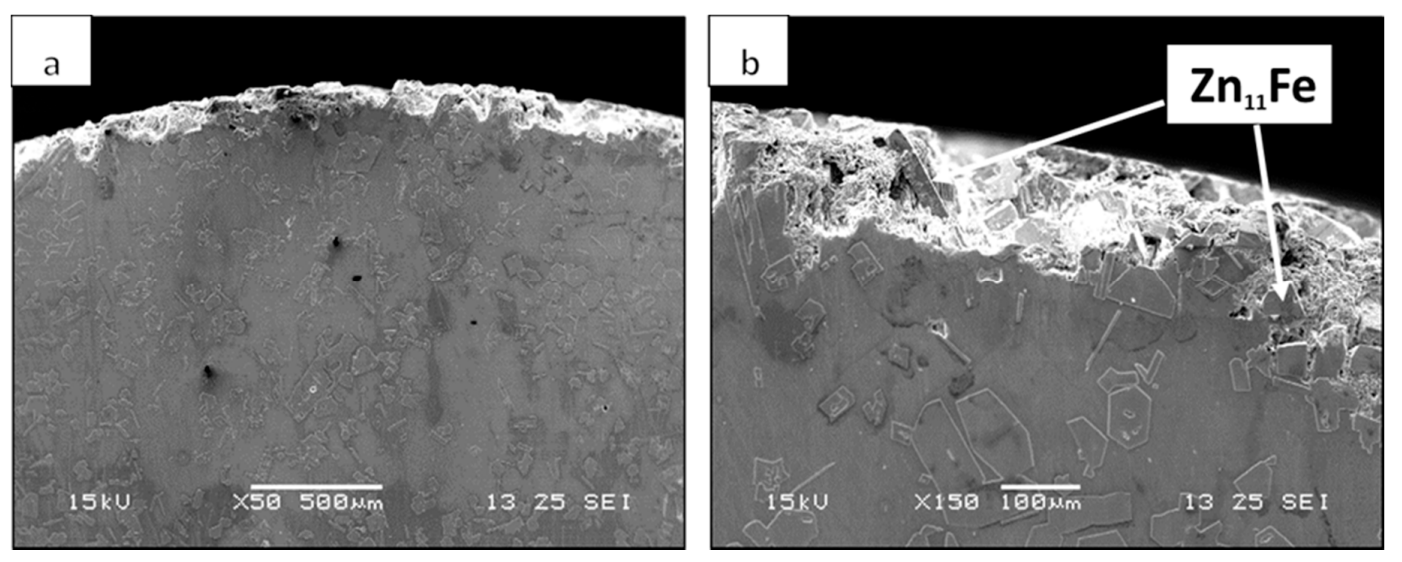

Figure 6. Surface cross section showing corrosion attack of $\mathrm{Zn}-1.3 \% \mathrm{Fe}$ alloy after 10 days of exposure: (a) Macro view. (b) Close-up view.

The electrochemical analysis by potentiodynamic polarization is shown in Figure 7, and the corresponding Tafel extrapolation measurements are listed in Table 3. The polarization curve of the $\mathrm{Zn}-1.3 \% \mathrm{Fe}$ alloy shifted to higher current densities compared to pure $\mathrm{Zn}$, indicating a reduced corrosion resistance. Tafel extrapolation obtained from the polarization curves support this observation, identifying a corrosion rate of 0.013 millimeter per year $(\mathrm{mm} / \mathrm{y})$ for $\mathrm{Zn}-1.3 \% \mathrm{Fe}$ compared to $0.010 \mathrm{~mm} / \mathrm{y}$ for the pure $\mathrm{Zn}$ sample.

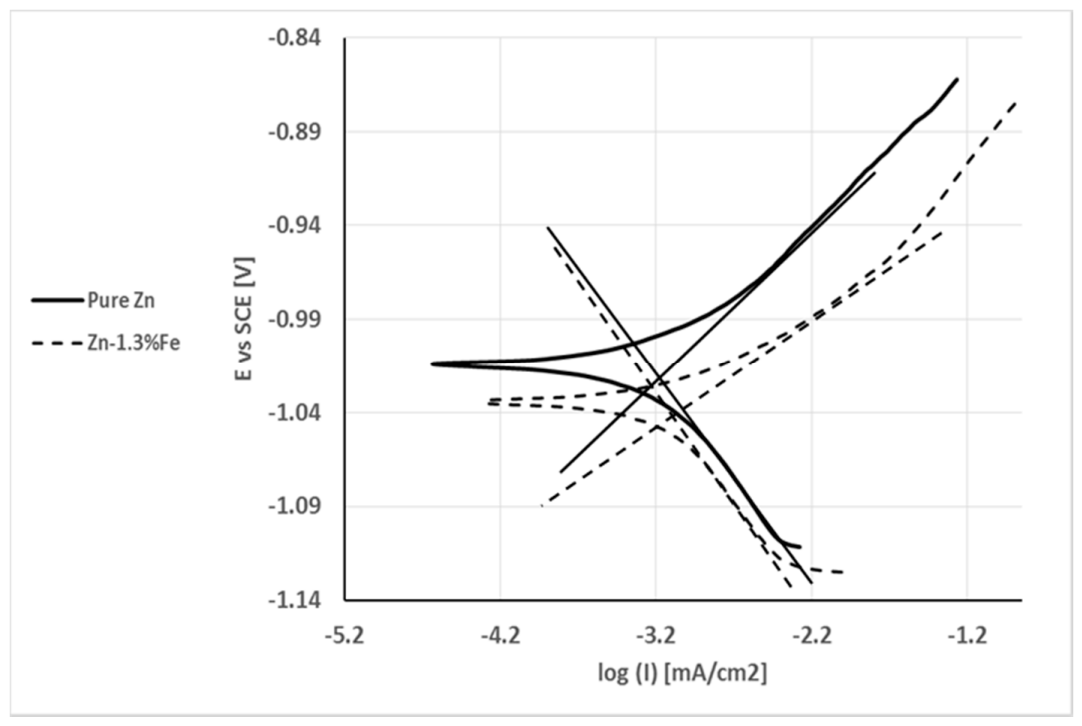

Figure 7. Potentiodynamic polarization curves obtained in PBS solution.

Table 3. Corrosion potential ( $\left.\mathrm{E}_{\mathrm{corr}}\right)$, corrosion current $\left(\mathrm{I}_{\mathrm{corr}}\right)$ and corrosion rate (C.R.) obtained by Tafel extrapolation from polarization curves shown in Figure 7.

\begin{tabular}{ccccc}
\hline C.R $(\mathbf{m m} / \mathbf{y})$ & Icorr $\left(\boldsymbol{\mu} \mathbf{A} / \mathbf{c m}^{2}\right)$ & Ecorr $(\mathbf{V})$ & Parameter Specimen & C.R $(\mathbf{m m} / \mathbf{y})$ \\
\hline 0.010 & 0.67 & -1.02 & Pure Zn & 0.010 \\
0.013 & 0.89 & -1.04 & $\mathrm{Zn}-1.3 \% \mathrm{Fe}$ & 0.013 \\
\hline
\end{tabular}


The impedance spectroscopy analysis in terms of impedance modifications after immersion times of 1 and $48 \mathrm{~h}$ in PBS solution are shown by Nyquist plots in Figure 8 and Bode plots in Figure 9. The relatively larger radius of curvature in the Nyquist diagram of the pure $\mathrm{Zn}$ sample indicates that its corrosion resistance was significantly increased compared to the $\mathrm{Zn}-1.3 \% \mathrm{Fe}$ sample. Bode diagrams reveal that after one hour of exposure to the PBS solution, the corrosion resistance of both samples are nearly the same (around 10,000 $\mathrm{Ohm}$ ), while after $48 \mathrm{~h}$ of exposure the corrosion resistance of the $\mathrm{Zn}-1.3 \% \mathrm{Fe}$ sample decreased from about $8130 \mathrm{Ohm}$ to $4365 \mathrm{Ohm}$. The results obtained by the potentiodynamic polarization and impedance spectroscopy analysis are in accordance with the results from the immersion tests.

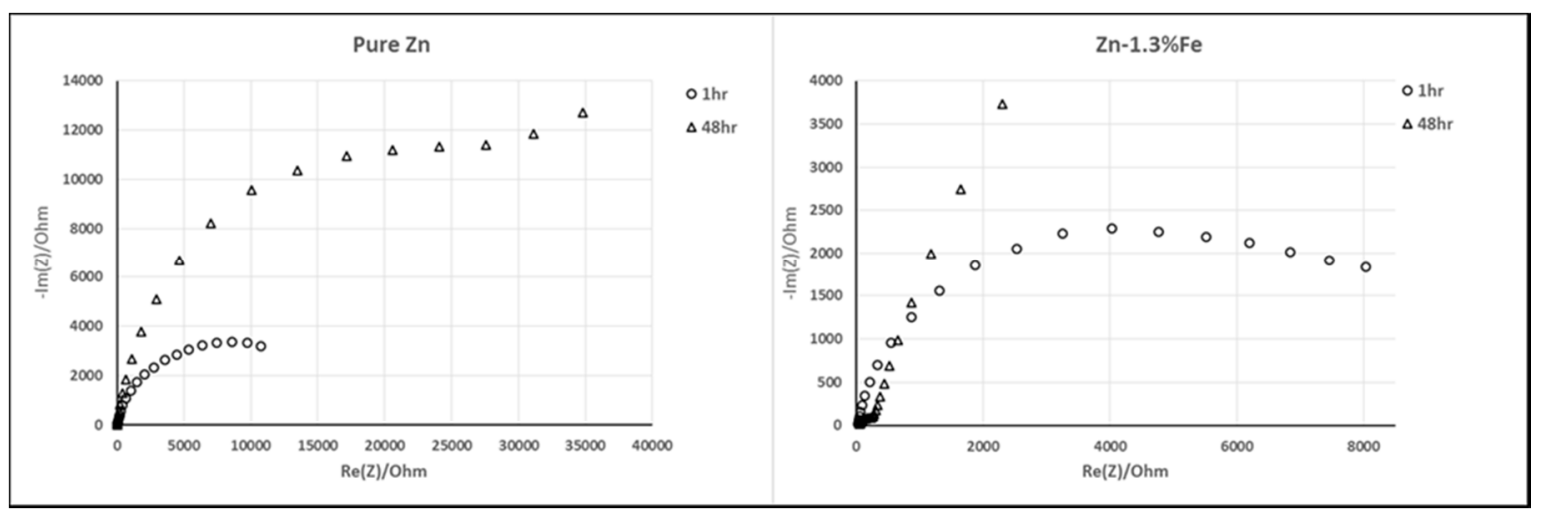

Figure 8. Nyquist plots obtained after immersion in PBS solution for up to $48 \mathrm{~h}$.



Figure 9. Bode plots obtained after immersion in PBS solution for up to $48 \mathrm{~h}$.

The in vivo evaluation demonstrated a normal weight gain for all the rats irrespective of implant type $\mathrm{Zn}$, Figure 10. Post-implantation behavior, cage locomotion and surgical wound appearance were all normal, with no signs of compromised health.

Zinc serum levels and blood biochemical parameters (RBC, HGB and WBC) examined before and after implantation are shown in Figures 11-14. The Zn content was slightly increased in the case of pure $\mathrm{Zn}$ and $\mathrm{Zn}-1.3 \% \mathrm{Fe}$ implantations compared to titanium, as expected, but in all cases was within the normal range of 168-190 [ $\mu \mathrm{g} / \mathrm{dL}]$ [57]. Furthermore, none of the implanted samples exerted a negative effect on the hematological profiles of the rats, as all of the measurements were within the normal range [58]: RBC 7.62-9.99 [106/ $\mu \mathrm{L}$ ], HGB 13.6-17.4 [g/dL], WBC 1.98-11.06 [103/ $\mu \mathrm{L}]$.

The corrosion rate of pure $\mathrm{Zn}$ and $\mathrm{Zn}-1.3 \% \mathrm{Fe}$ implants at 14 weeks post implantation are shown in Figure 15. The corrosion rate of $\mathrm{Zn}-1.3 \% \mathrm{Fe}$ was significantly increased relative to pure $\mathrm{Zn}$. 


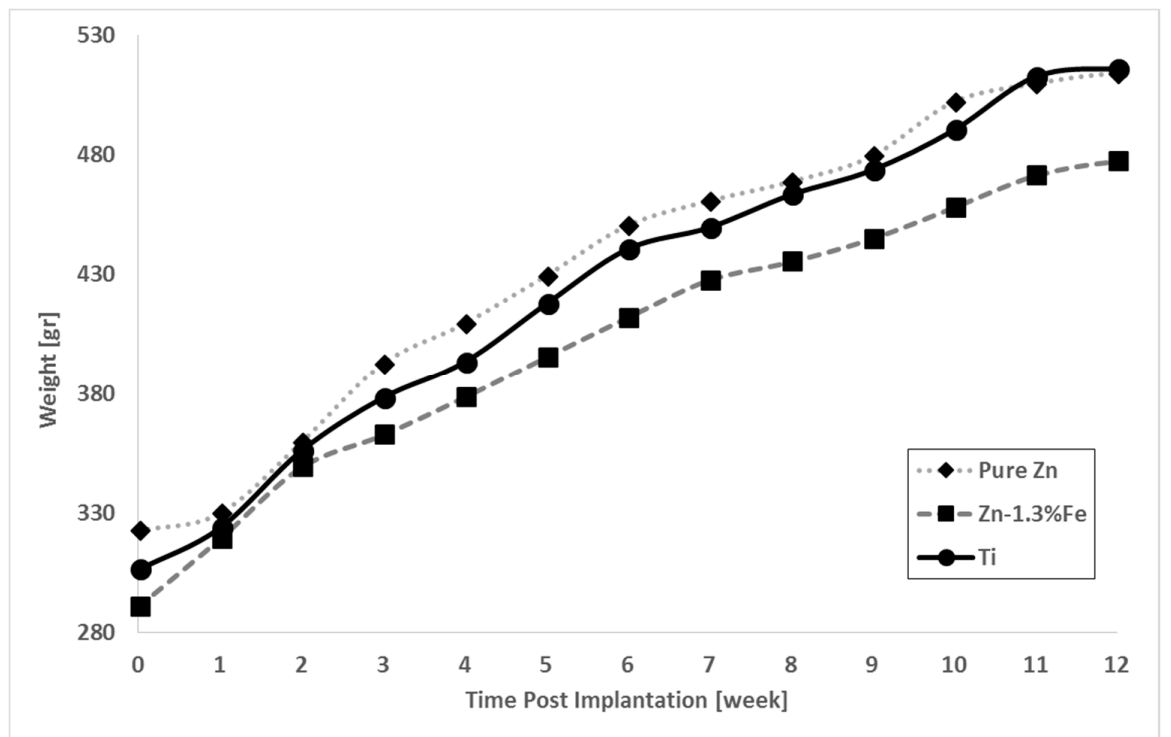

Figure 10. Rat body weights pre- and post-implantation.



Figure 11. Serum Zinc level pre- and post-implantation.

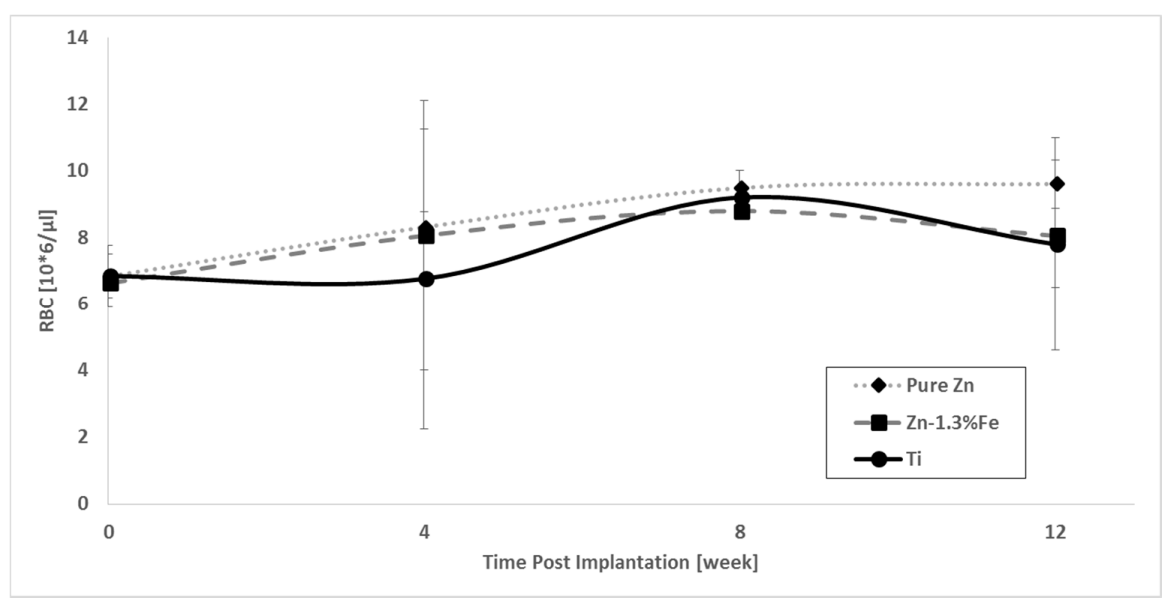

Figure 12. Red blood cells (RBC) level pre- and post-implantation. 




Figure 13. Hemoglobin (HGB) level pre- and post-implantation.

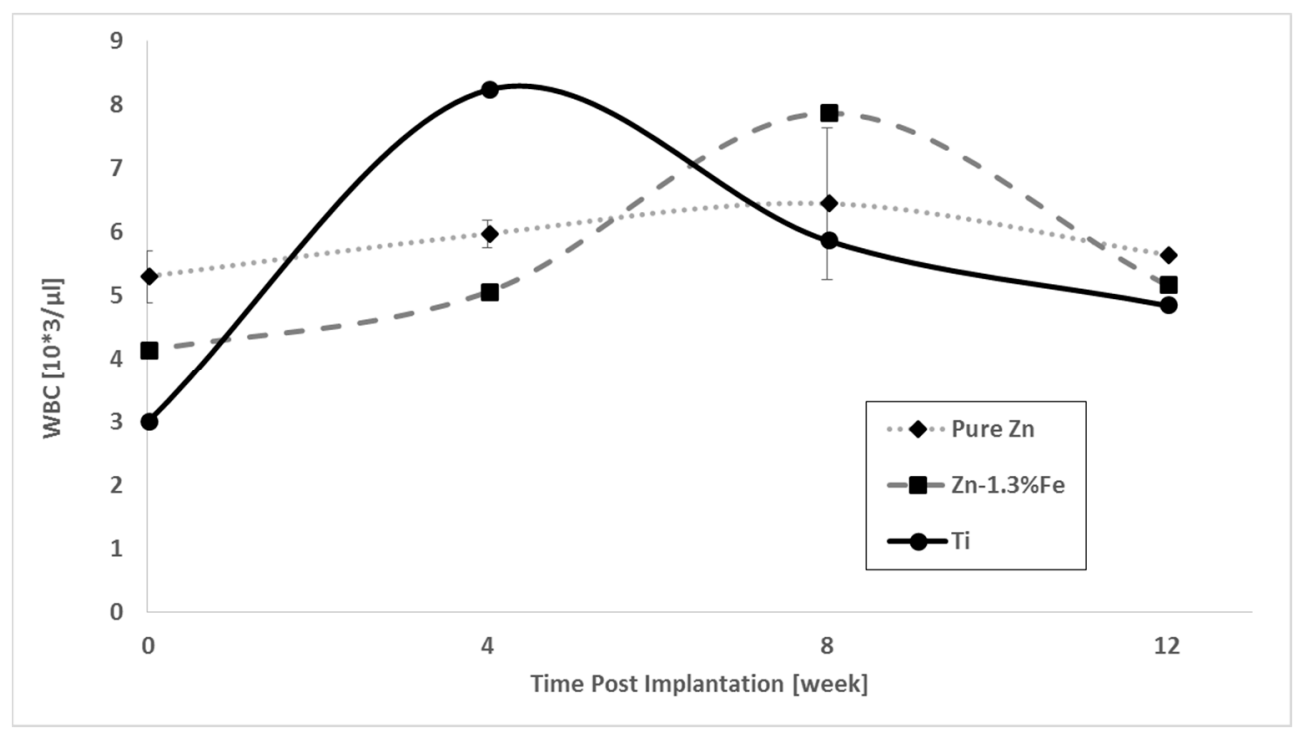

Figure 14. White blood cells (WBC) level pre- and post-implantation.

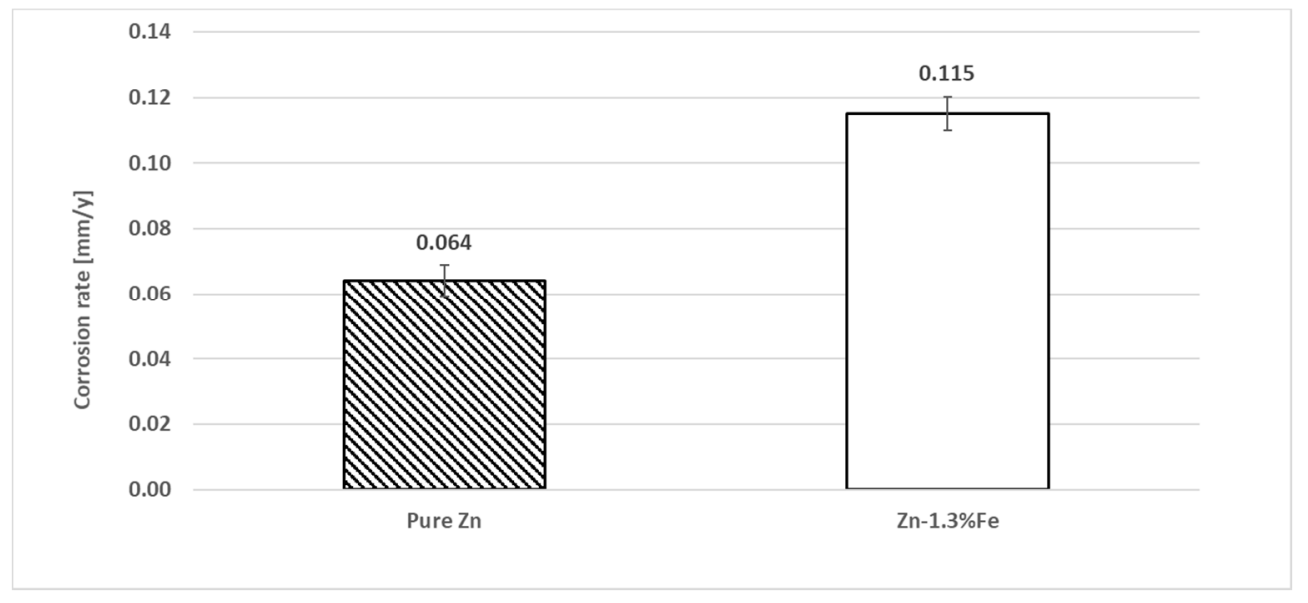

Figure 15. Corrosion rate of pure $\mathrm{Zn}$ and $\mathrm{Zn}-1.3 \%$ Fe implants after 14 weeks of implantation.

Histology analyses of the subcutaneous tissue around the tested implants (pure $\mathrm{Zn}, \mathrm{Zn}-1.3 \% \mathrm{Fe}$ and Ti-6Al-4V as reference alloy) at 14 weeks post-implantation are shown in Figure 16. None of 
the zinc-bearing implants promoted a negative effect on the live tissue or provoked an inflammatory response compared to the reference Ti alloy.

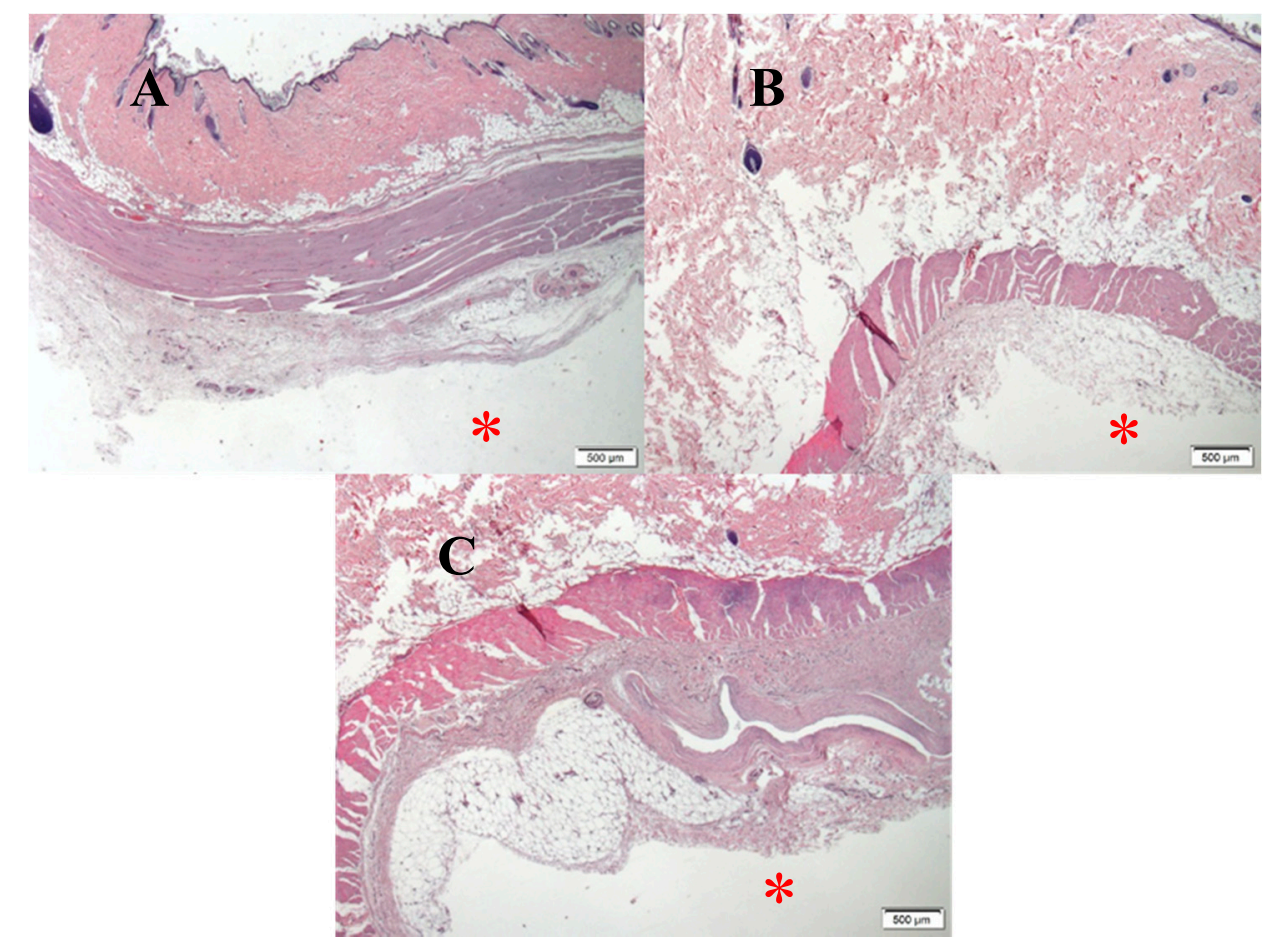

Figure 16. Histological analysis of subcutaneous tissue in the vicinity of the implants. (A) Pure Zn; (B) $\mathrm{Zn}-1.3 \% \mathrm{Fe}$; (C) Ti-6Al-4V. * marks the implants location.

\section{Discussion}

Biodegradable implants that strongly resist corrosion in physiological environments may elicit negative inflammatory responses, as macrophages increase their activity to metabolize foreign material [27]. Indeed, earlier in vivo work with zinc vascular implants demonstrated that the corrosion rate may be a critical regulator of inflammation [27]. In this work, we were surprised to find that the highest purity zinc implant ( $\sim 0.01 \mathrm{wt} \%$ impurities) produced the strongest negative inflammatory response, and introductions of mainly iron impurities of $\sim 0.3 \mathrm{wt} \%$ into the implant substantially ameliorated the inflammatory response. This discovery raised the intriguing prospect that inflammatory responses to zinc implants could be controlled by the implant's corrosion behavior. In the present proof of concept work, we intended to develop a zinc alloy system that imparts tunable corrosion rates (by adjusting alloying element concentration) in order to regulate inflammatory responses. Herein, we have developed such an implant material as well as characterized the effects of alloying on material properties. The ultimate goal, not pursued in the present study, is to identify an optimal corrosion rate for avoiding harmful inflammation when deploying zinc based medical implants.

Several methods can be used to increase the corrosion rate of pure zinc. These methods include surface film modification, coatings, microstructure manipulation via thermal and mechanical processing, and alloying. The intent of the present study was to use the biocompatible alloying element Fe to produce micro-galvanic effects to increase the corrosion rate of pure zinc. This approach was also adopted by other researchers, for instance in $\mathrm{Zn}-\mathrm{Cu}$ base systems such as $\mathrm{Zn}-\mathrm{Cu}$, by Niu et al. [40], $\mathrm{Zn}-\mathrm{Cu}-\mathrm{Mg}$ by Tang et al. [44] and $\mathrm{Zn}-3 \mathrm{Cu}$ by Yue et al. [36]. The use of $\mathrm{Cu}$ as an alloying element to produce a micro-galvanic effect was justified by the higher standard potential of $\mathrm{Cu}$ ( $0.337 \mathrm{~V}$ compared to $-0.763 \mathrm{~V}$ for Zinc) as well as the micro-galvanic effects generated by a secondary 
phase $\mathrm{CuZn}_{5}$. The potential to achieve a micro-galvanic effect in the present study is based on the elevated electrochemical potential of all $\mathrm{Zn}-\mathrm{Fe}$ precipitate phases relative to pure zinc. The potentials of Zn-Fe phases as identified by Lee et al. [53] are as follows (vs. SCE): Delta phase $-0.822 \mathrm{~V}$, Zeta phase $-0.940 \mathrm{~V}$, Gamma phase $-0.772 \mathrm{~V}$, while pure zinc is $-1.03 \mathrm{~V}$.

In-vitro examination of the gravity cast $\mathrm{Zn}-1.3 \% \mathrm{Fe}$ alloy demonstrated a nearly $100 \%$ increase in corrosion rate compared to pure zinc. This was supported by the electrochemical analysis in terms of potentiodynamic polarization and impedance examination as well as the in vivo corrosion rate measurements at 14 weeks post implantation. The mechanical properties of pure zinc in as cast conditions obtained by this study are in line with the reported results of Gong et al. [37], and $\mathrm{Li}$ et al. [39]. The increased strength of $\mathrm{Zn}-1.3 \% \mathrm{Fe}$ with concomitant reduction in ductility is attributed to the effect of $\mathrm{Fe}$ as an alloying element. Nevertheless, the strength and ductility of $\mathrm{Zn}-1.3 \% \mathrm{Fe}$ alloy in the as cast condition are still relatively low. In order to improve these properties, additional metal forming processing, such as hot extrusion [59], are required to obtain an adequate structural material for practical degradable implant applications.

The in vivo study demonstrated that the pure $\mathrm{Zn}$ and $\mathrm{Zn}-1.3 \% \mathrm{Fe}$ alloy avoided negative systemic effects on the wellbeing behavior and normal growth of the rats during the 12 weeks of implantation. Furthermore, the implantation of these two materials did not increase the amount of zinc in blood beyond the acceptable level. This was supported by the absence of anemia in terms of RBC and HGB levels. In addition, there were no signs of infection following implantation of either $\mathrm{Zn}$ base system, as there was no increase in the amount of white blood cells (WBC). This was confirmed by the histology analyses of subcutaneous tissue in the vicinity of the tested $\mathrm{Zn}$ base implants. Although not performed directly at the implant-tissue interface, the histology shows a general absence of harmful effects at 14 weeks post implantation from the implant or corrosion activity. The corrosion rate of pure $\mathrm{Zn}$ and $\mathrm{Zn}-1.3 \% \mathrm{Fe}$ alloy under in vivo conditions was relatively reduced compared to their corrosion rate under in vitro conditions. This result is in accordance with the observations of Torne et al. [56], and Witte et al. [60] who have reported that the aggressiveness of the in vivo physiological environment towards the biodegradable metal implants is relatively lower compared to the in vitro submersion of metals under PBS solution. Further contributing to the disparity, the two cylindrical disks implanted in the midline of the back of the rats were exposed to a relatively low blood flow that practically generates a relatively reduced corrosion attack compared to the in vitro conditions.

Together, the results of the present study indicate that $\mathrm{Zn}-1.3 \% \mathrm{Fe}$ alloy can significantly increase the corrosion rate of pure $\mathrm{Zn}$. Consequently, this alloy can overcome the inherent low degradation rate of pure $\mathrm{Zn}$ and can be considered as a potential structural material candidate for biodegradable $\mathrm{Zn}$ base implants.

\section{Conclusions}

Alloying of $\mathrm{Zn}$ with Fe at a concentration of $1.3 \mathrm{wt} \%$ nearly doubled the corrosion rate in in vitro and in vivo conditions. The relatively higher corrosion of $\mathrm{Zn}-1.3 \% \mathrm{Fe}$ is attributed to the microgalvanic effect generated mainly by the formation of Delta phase $\left(\mathrm{Zn}_{11} \mathrm{Fe}\right)$. The absence of undesirable systemic effects, including weight growth, wellbeing activities and hematological characteristics (RBC, HGB and WBC) of the rats during 14 weeks of implantation, as well as obtaining adequate histology results in subcutaneous tissue close to the tested implants suggests that the $\mathrm{Zn}-1.3 \% \mathrm{Fe}$ alloy can be considered as a potential material for biodegradable implants.

Acknowledgments: The authors would like to thank Avi Leon for his assistance in the experimental work.

Author Contributions: Eli Aghion and Alon Kafri conceived and designed the experiments; Alon kafri and Shira Ovadia performed the experiments; Eli Aghion, Alon Kafri, Jeremy Goldman and Jaroslaw Drelich analyzed the data; Eli Aghion and Alon Kafri wrote the paper.

Conflicts of Interest: The authors declare no conflict of interest. 


\section{References}

1. Schinhammer, M.; Hänzi, A.C.; Löffler, J.F.; Uggowitzer, P.J. Design strategy for biodegradable Fe-based alloys for medical applications. Acta Biomater. 2010, 6, 1705-1713. [CrossRef] [PubMed]

2. Peuster, M.; Wohlsein, P.; Brugmann, M.; Ehlerding, M.; Seidler, K.; Fink, C.; Brauer, H.; Fischer, A.; Hausdorf, G. A novel approach to temporary stenting: Degradable cardiovascular stents produced from corrodible metal-results 6-18 months after implantation into New Zealand white rabbits. Heart 2001, 86, 563-569. [CrossRef] [PubMed]

3. Feng, Q.; Zhang, D.; Xin, C.; Liu, X.; Lin, W.; Zhang, W.; Chen, S.; Sun, K. Characterization and in vivo evaluation of a bio-corrodible nitrided iron stent. J. Mater. Sci. Mater. Med. 2013, 24, 713-724. [CrossRef] [PubMed]

4. Mueller, P.P.; Arnold, S.; Badar, M.; Bormann, D.; Bach, F.W.; Drynda, A.; Meyer-Lindenberg, A.; Hauser, H.; Peuster, M. Histological and molecular evaluation of iron as degradable medical implant material in a murine animal model. J. Biomed. Mater. Res. Part A 2012, 100A, 2881-2889. [CrossRef] [PubMed]

5. Liu, B.; Zheng, Y.F. Effects of alloying elements (Mn, Co, Al, W, Sn, B, C and S) on biodegradability and in vitro biocompatibility of pure iron. Acta Biomater. 2011, 7, 1407-1420. [CrossRef] [PubMed]

6. Pierson, D.; Edick, J.; Tauscher, A.; Pokorney, E.; Bowen, P.; Gelbaugh, J.; Stinson, J.; Getty, H.; Lee, C.H.; Drelich, J.; et al. A simplified in vivo approach for evaluating the bioabsorbable behavior of candidate stent materials. J. Biomed. Mater. Res. Part B Appl. Biomater. 2012, 100B, 58-67. [CrossRef] [PubMed]

7. Bowen, P.K.; Drelich, J.; Buxbaum, R.E.; Rajachar, R.M.; Goldman, J. New approaches in evaluating metallic candidates for bioabsorbable stents. Emerg. Mater. Res. 2012, 1, 237-255. [CrossRef]

8. Schümann, K.; Ettle, T.; Szegner, B.; Elsenhans, B.; Solomons, N.W. On risks and benefits of iron supplementation recommendations for iron intake revisited. J. Trace Elem. Med. Biol. 2007, 21, 147-168. [CrossRef] [PubMed]

9. Staiger, M.P.; Pietak, A.M.; Huadmai, J.; Dias, G. Magnesium and its alloys as orthopedic biomaterials: A review. Biomaterials 2006, 27, 1728-1734. [CrossRef] [PubMed]

10. Chen, D.; He, Y.; Tao, H.; Zhang, Y.; Jiang, Y.; Zhang, X.; Zhang, S. Biocompatibility of magnesium-zinc alloy in biodegradable orthopedic implants. Int. J. Mol. Med. 2011, 28, 343-348. [PubMed]

11. Dunne, C.F.; Levy, G.K.; Hakimi, O.; Aghion, E.; Twomey, B.; Stanton, K.T. Corrosion behaviour of biodegradable magnesium alloys with hydroxyapatite coatings. Surf. Coat. Technol. 2016, 289, 37-44. [CrossRef]

12. Hakimi, O.; Aghion, E. Corrosion performance of biodegradable Mg- $6 \% \mathrm{Nd}-2 \% \mathrm{Y}-0.5 \% \mathrm{Zr}$ produced by melt spinning technology. Adv. Eng. Mater. 2014, 16, 364-370. [CrossRef]

13. Zhang, S.; Zhang, X.; Zhao, C.; Li, J.; Song, Y.; Xie, C.; Tao, H.; Zhang, Y.; He, Y.; Jiang, Y. Research on an $\mathrm{Mg}-\mathrm{Zn}$ alloy as a degradable biomaterial. Acta Biomater. 2010, 6, 626-640. [CrossRef] [PubMed]

14. Persaud-Sharma, D.; McGoron, A. Biodegradable Magnesium Alloys: A Review of Material Development and Applications. J. Biomim. Biomater. Tissue Eng. 2012, 12, 25-39. [CrossRef] [PubMed]

15. Song, G. Control of biodegradation of biocompatable magnesium alloys. Corros. Sci. 2007, 49, $1696-1701$. [CrossRef]

16. Ghali, E. Testing of Aluminum, Magnesium, and Their Alloys. In Uhlig's Corrosion Handbook, 3rd ed.; John Wiley \& Sons, Inc.: Hoboken, NJ, USA, 2011; pp. 1103-1106.

17. Hakimi, O.; Aghion, E.; Goldman, J. Improved stress corrosion cracking resistance of a novel biodegradable EW62 magnesium alloy by rapid solidification, in simulated electrolytes. Mater. Sci. Eng. C 2015, 51, $226-232$. [CrossRef] [PubMed]

18. Aghion, E.; Levy, G. The effect of Ca on the in vitro corrosion performance of biodegradable $\mathrm{Mg}-\mathrm{Nd}-\mathrm{Y}-\mathrm{Zr}$ alloy. J. Mater. Sci. 2010, 45, 3096-3101. [CrossRef]

19. Levy, G.; Aghion, E. Effect of diffusion coating of $\mathrm{Nd}$ on the corrosion resistance of biodegradable $\mathrm{Mg}$ implants in simulated physiological electrolyte. Acta Biomater. 2013, 9, 8624-8630. [CrossRef] [PubMed]

20. Cheng, J.; Liu, B.; Wu, Y.H.; Zheng, Y.F. Comparative invitro study on pure metals (Fe, Mn, Mg, Zn and W) as biodegradable metals. J. Mater. Sci. Technol. 2013, 29, 619-627. [CrossRef]

21. Bowen, P.K.; Shearier, E.R.; Zhao, S.; Guillory, R.J., II; Zhao, F.; Goldman, J.; Drelich, J.W. Biodegradable Metals for Cardiovascular Stents: From Clinical Concerns to Recent Zn-Alloys. Adv. Healthc. Mater. 2016, 5, 1121-1140. [CrossRef] [PubMed] 
22. Bowen, P.K.; Drelich, J.; Goldman, J. Zinc exhibits ideal physiological corrosion behavior for bioabsorbable stents. Adv. Mater. 2013, 25, 2577-2582. [CrossRef] [PubMed]

23. Hennig, B.; Toborek, M.; McClain, C.J. Antiatherogenic properties of zinc: Implications in endothelial cell metabolism. Nutrition 1996, 12, 711-717. [CrossRef]

24. Al-Maroof, R.A.; Al-Sharbatti, S.S. Serum zinc levels in diabetic patients and effect of zinc supplementation on glycemic control of type 2 diabetics. Saudi Med. J. 2006, 27, 344-350. [PubMed]

25. Hambidge, K.M.; Krebs, N.F. Zinc Deficiency: A Special Challenge. J. Nutr. 2007, 137, 1101-1105. [CrossRef] [PubMed]

26. Plum, L.M.; Rink, L.; Hajo, H. The essential toxin: Impact of zinc on human health. Int. J. Environ. Res. Public Health 2010, 7, 1342-1365. [CrossRef] [PubMed]

27. Guillory, R.J.; Bowen, P.K.; Hopkins, S.P.; Shearier, E.R.; Earley, E.J.; Gillette, A.A.; Aghion, E.; Bocks, M.; Drelich, J.W.; Goldman, J. Corrosion Characteristics Dictate the Long-Term Inflammatory Profile of Degradable Zinc Arterial Implants. ACS Biomater. Sci. Eng. 2016, 2, 2355-2364. [CrossRef]

28. Drelich, A.J.; Zhao, S.; Guillory, R.J.; Drelich, J.W.; Goldman, J. Long-term surveillance of zinc implant in murine artery: Surprisingly steady biocorrosion rate. Acta Biomater. 2017, 58, 539-549. [CrossRef] [PubMed]

29. Bowen, P.K.; Guillory, R.J., II; Shearier, E.R.; Seitz, J.-M.; Drelich, J.; Bocks, M.; Zhao, F.; Goldman, J. Metallic zinc exhibits optimal biocompatibility for bioabsorbable endovascular stents. Mater. Sci. Eng. C 2015, 56, 467-472. [CrossRef] [PubMed]

30. Smith, S.E.; Lakson, E.J. Zinc toxicity in rats; antagonistic effects of copper and liver. J. Biol. Chem. 1946, 163, 29-38. [PubMed]

31. Piao, F.; Yokoyama, K.; Ma, N.; Yamauchi, T. Subacute toxic effects of zinc on various tissues and organs of rats. Toxicol. Lett. 2003, 145, 28-35. [CrossRef]

32. Drelich, A.J.; Bowen, P.K.; LaLonde, L.; Goldman, J.; Drelich, J.W. Importance of oxide film in endovascular biodegradable zinc stents. Surf. Innov. 2016, 4, 133-140. [CrossRef]

33. Shomali, A.A.; Guillory, R.J.; Seguin, D.; Goldman, J.; Drelich, J.W. Effect of PLLA coating on corrosion and biocompatibility of zinc in vascular environment. Surf. Innov. 2017, 5, 211-220. [CrossRef]

34. Tjellström, A.; Rosenhall, U.; Lindström, J.; Hallén, O.; Albrektsson, T.; Brånemark, P.I. Five-Year Experience with Skin-Penetrating Bone-Anchored Implants in the Temporal Bone. Acta Otolaryngol. 1983, 95, 568-575. [CrossRef] [PubMed]

35. Geetha, M.; Singh, A.K.; Asokamani, R.; Gogia, A.K. Ti based biomaterials, the ultimate choice for orthopaedic implants-A review. Prog. Mater. Sci. 2009, 54, 397-425. [CrossRef]

36. Yue, R.; Huang, H.; Ke, G.; Zhang, H.; Pei, J.; Xue, G.; Yuan, G. Microstructure, mechanical properties and in vitro degradation behavior of novel Zn-Cu-Fe alloys. Mater. Charact. 2017, 134, 114-122. [CrossRef]

37. Gong, H.; Wang, K.; Strich, R.; Zhou, J.G. In vitro biodegradation behavior, mechanical properties, and cytotoxicity of biodegradable $\mathrm{Zn}-\mathrm{Mg}$ alloy. J. Biomed. Mater. Res. Part B Appl. Biomater. 2015, 103, 1632-1640. [CrossRef] [PubMed]

38. Vojtěch, D.; Kubásek, J.; Šerák, J.; Novák, P. Mechanical and corrosion properties of newly developed biodegradable Zn-based alloys for bone fixation. Acta Biomater. 2011, 7, 3515-3522. [CrossRef] [PubMed]

39. Li, H.F.; Xie, X.H.; Zheng, Y.F.; Cong, Y.; Zhou, F.Y.; Qiu, K.J.; Wang, X.; Chen, S.H.; Huang, L.; Tian, L.; et al. Development of biodegradable Zn-1X binary alloys with nutrient alloying elements Mg, Ca and Sr. Sci. Rep. 2015, 5, 10719. [CrossRef] [PubMed]

40. Zhao, S.; McNamara, C.T.; Bowen, P.K.; Verhun, N.; Braykovich, J.P.; Goldman, J.; Drelich, J.W. Structural Characteristics and In Vitro Biodegradation of a Novel Zn-Li Alloy Prepared by Induction Melting and Hot Rolling. Metall. Mater. Trans. A Phys. Metall. Mater. Sci. 2017, 48, 1204-1215. [CrossRef]

41. Bowen, P.K.; Seitz, J.M.; Guillory, R.J., II; Braykovich, J.P.; Zhao, S.; Goldman, J.; Drelich, J.W. Evaluation of wrought $\mathrm{Zn}-\mathrm{Al}$ alloys $(1,3$, and $5 \mathrm{wt} \% \mathrm{Al})$ through mechanical and in vivo testing for stent applications. J. Biomed. Mater. Res. Part B Appl. Biomater. 2018, 106, 245-258. [CrossRef] [PubMed]

42. Zhao, S.; Seitz, J.M.; Eifler, R.; Maier, H.J.; Guillory, R.J., II; Earley, E.J.; Drelich, A.; Goldman, J.; Drelich, J.W. $\mathrm{Zn}$-Li alloy after extrusion and drawing: Structural, mechanical characterization, and biodegradation in abdominal aorta of rat. Mater. Sci. Eng. C 2017, 76, 301-312. [CrossRef] [PubMed]

43. Niu, J.; Tang, Z.; Huang, H.; Pei, J.; Zhang, H.; Yuan, G.; Ding, W. Research on a Zn-Cu alloy as a biodegradable material for potential vascular stents application. Mater. Sci. Eng. C 2016, 69, 407-413. [CrossRef] [PubMed] 
44. Tang, Z.; Huang, H.; Niu, J.; Zhang, L.; Zhang, H.; Pei, J.; Tan, J.; Yuan, G. Design and characterizations of novel biodegradable Zn-Cu-Mg alloys for potential biodegradable implants. Mater. Des. 2017, 117, 84-94. [CrossRef]

45. Bakhsheshi-Rad, H.R.; Hamzah, E.; Low, H.T.; Kasiri-Asgarani, M.; Farahany, S.; Akbari, E.; Cho, M.H. Fabrication of biodegradable Zn-Al-Mg alloy: Mechanical properties, corrosion behavior, cytotoxicity and antibacterial activities. Mater. Sci. Eng. C 2017, 73, 215-219. [CrossRef] [PubMed]

46. Jin, H.; Zhao, S.; Guillory, R.; Bowen, P.K.; Yin, Z.; Griebel, A.; Schaffer, J.; Earley, E.J.; Goldman, J.; Drelich, J.W. Novel high-strength, low-alloys $\mathrm{Zn}-\mathrm{Mg}(<0.1 \mathrm{wt} \% \mathrm{Mg})$ and their arterial biodegradation. Mater. Sci. Eng. C 2017, 84, 67-79.

47. Dambatta, M.S.; Izman, S.; Kurniawan, D.; Hermawan, H. Processing of Zn-3Mg alloy by equal channel angular pressing for biodegradable metal implants. J. King Saud Univ. Sci. 2017, 29, 455-461. [CrossRef]

48. Mostaed, E.; Sikora-Jasinska, M.; Mostaed, A.; Loffredo, S.; Demir, A.G.; Previtali, B.; Mantovani, D.; Beanland, R.; Vedani, M. Novel Zn-based alloys for biodegradable stent applications: Design, development and in vitro degradation. J. Mech. Behav. Biomed. Mater. 2016, 60, 581-602. [CrossRef] [PubMed]

49. Bagha, P.S.; Khaleghpanah, S.; Sheibani, S.; Khakbiz, M.; Zakeri, A. Characterization of nanostructured biodegradable Zn-Mn alloy synthesized by mechanical alloying. J. Alloys Compd. 2018, 735, 1319-1327. [CrossRef]

50. Xiao, C.; Wang, L.; Ren, Y.; Sun, S.; Zhang, E.; Yan, C.; Liu, Q.; Sun, X.; Shou, F.; Duan, J.; et al. Indirectly extruded biodegradable $\mathrm{Zn}-0.05 \mathrm{wt} \% \mathrm{Mg}$ alloy with improved strength and ductility: In vitro and in vivo studies. J. Mater. Sci. Technol. 2018. [CrossRef]

51. Zhang, Y.; Li, J.; Li, J. Microstructure, mechanical properties, corrosion behavior and film formation mechanism of Mg-Zn-Mn-xNd in Kokubo's solution. J. Alloys Compd. 2018, 730, 458-470. [CrossRef]

52. Fransen, M.; Nazikkol, C. Zinc/Iron Phase Transformation Studies on Galvannealed Steel Coatings By X-ray Diffraction. Advances 2003, 46, 291-296.

53. Lee, H.H.; Hiam, D. Corrosion resistance of galvannealed steel. Corrosion 1989, 45, 852-856. [CrossRef]

54. Yun, Y.; Dong, Z.; Yang, D.; Schulz, M.J.; Shanov, V.N.; Yarmolenko, S.; Xu, Z.; Kumta, P.; Sfeir, C. Biodegradable Mg corrosion and osteoblast cell culture studies. Mater. Sci. Eng. C 2009, 29, 1814-1821. [CrossRef]

55. Jaiswal, S.; Kumar, R.M.; Gupta, P.; Kumaraswamy, M.; Roy, P.; Lahiri, D. Mechanical, corrosion and biocompatibility behaviour of Mg-3Zn-HA biodegradable composites for orthopaedic fixture accessories. J. Mech. Behav. Biomed. Mater. 2018, 78, 442-454. [CrossRef] [PubMed]

56. Törne, K.; Larsson, M.; Norlin, A.; Weissenrieder, J. Degradation of zinc in saline solutions, plasma, and whole blood. J. Biomed. Mater. Res. Part B Appl. Biomater. 2016, 104, 1141-1151. [CrossRef] [PubMed]

57. Yur, F.; Bildik, A.; Belge, F.; Kilicalp, D. Serum Plasma and Erythrocyte Zinc levels in various animal species. VAN Vet. J. 2002, 13, 82-83.

58. Quesenberry, K.E.; Carpenter, J.W. Small Rodents. In Ferrets, Rabbits and Rodents: Clinical Medicine and Surgery; Elsevier: St. Louis, MO, USA, 2003; p. 348.

59. Sikora-Jasinska, M.; Mostaed, E.; Mostaed, A.; Beanland, R.; Mantovani, D.; Vedani, M. Fabrication, mechanical properties and in vitro degradation behavior of newly developed $\mathrm{Zn}$ Ag alloys for degradable implant applications. Mater. Sci. Eng. C 2017, 77, 1170-1181. [CrossRef] [PubMed]

60. Witte, F.; Fischer, J.; Nellesen, J.; Crostack, H.A.; Kaese, V.; Pisch, A.; Beckmann, F.; Windhagen, H. In vitro and in vivo corrosion measurements of magnesium alloys. Biomaterials 2006, 27, 1013-1018. [CrossRef] [PubMed]

(C) 2018 by the authors. Licensee MDPI, Basel, Switzerland. This article is an open access article distributed under the terms and conditions of the Creative Commons Attribution (CC BY) license (http://creativecommons.org/licenses/by/4.0/). 